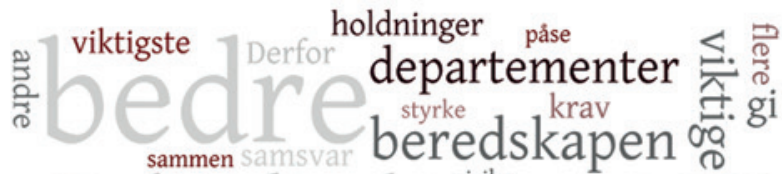

Politidirek toriso ${ }^{\text {risto }}$ et egen

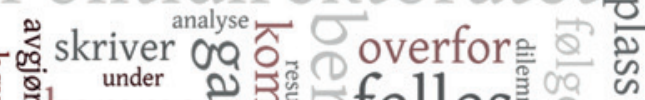

帘

nye hensyn

etablere

Forsvaret vurdere

产

产

departement

forskjellige trygghet frem

bidra sikkerhets

bruke 2 ans Var

annet $\curvearrowright$

samhandling arbeid

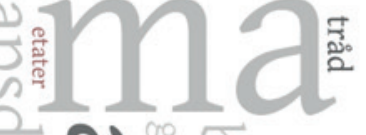

\title{
.
}

Direktoratet

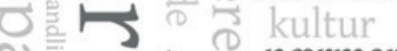

3 nærmere
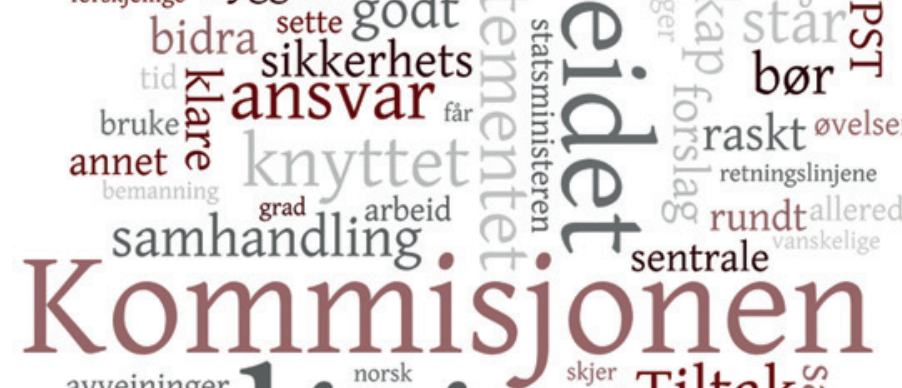

avveininger - ${ }^{\text {norsk }}$ hendelser 1 Tiltakj

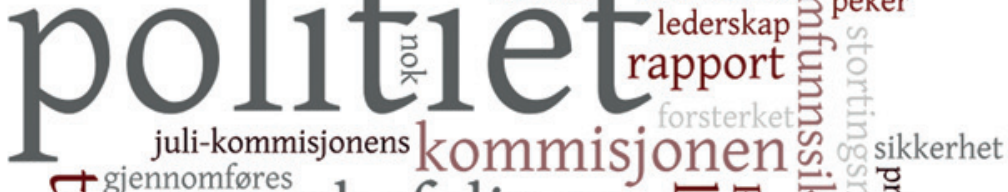

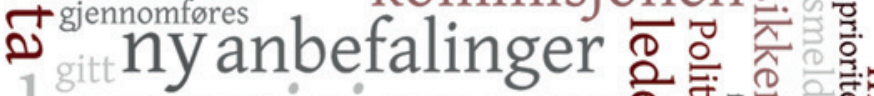

kommisjonens $\frac{0}{0}$ 范 bruk
overordnet tiltak
giennomfer gjennomføre rask. styring, riktig के के jobber Arbeidet ytterligere regjeringen $\begin{aligned} & \text { endringer } \\ & \text { के politi }\end{aligned}$ 
Charlotte Haug (f. 1959) er dr.med. og har en mastergrad i helsetjenesteforskning fra Stanford University. Hun har vært redaktør av Tidsskrift for

Den norske legeforening siden 2002.

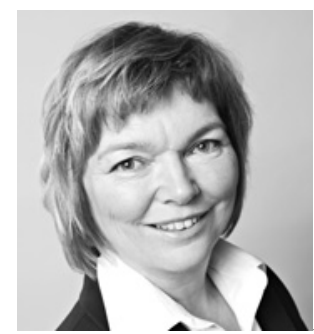

Foto Einar Nilsen

Hvis 22. juli hadde skjedd i helsevesenet, ville vi fått en Sønderland-rapport eller en Gjørv-rapport?

\section{Kunne det vært oss?}

«Yes, 'n' how many times can a man turn his head, Pretending he just doesn't see?» Bob Dylan, Blowin' in the Wind, 1962

Det tok meg litt tid å identifisere hvorfor jeg følte meg så uvel i dagene etter offentliggjøringen av rapporten fra 22. juli-kommisjonen (1). Det var mange åpenbare grunner til å føle seg utilpass: Gjenoppfriskningen av de grusomme detaljene, de hjerteskjærende scenene, de voldsomme ødeleggelsene. Alt som gikk galt som ikke burde gått galt, selv i en kaotisk situasjon: Ledelsen i politiet som ikke «trykte på den største knappen» til tross for at alle raskt forsto at det dreide seg om terror - enten fordi de ikke visste om planene (nyansatt politidirektør), fordi de ikke tenkte på det (flere) eller fordi de manglet passord for å komme inn på PC-en der terrorplanene lå (ansvarlig stabsperson i Politidirektoratet). Og selvfølgelig den ulykksalige historien om den gule lappen med de helt avgjørende opplysningene om gjerningsmannen og fluktbilen - som ble liggende til det var altfor sent.

At politiet hadde hatt opplysningene på den gule lappen umiddelbart etter eksplosjonen i Regjeringskvartalet, var omtalt i en NTB-melding allerede i august 2011 (2). Men hvorfor opplysningene ikke straks ble brukt til å prøve å stoppe bilen, ble klart først da rapporten kom: Lappen var blitt liggende på en pult. Da etterlysning endelig ble sendt ut, var den uklar - og nådde ikke frem dit den skulle. NTBmeldingen var en forsmak på hva vi senere skulle få vite om manglende risikoforståelse og beredskapskapskultur i statsforvaltningen. Jeg siterer: «Lederen for sikkerhetsavdelingen i Regjeringskvartalet, Jon Ivar Mehus, sier at de ikke ser på hensatte biler som en alvorlig trussel. (...) Det er noe som skjer jevnlig hos oss, sier Mehus, som forteller at det er mer mistenkelig hvis det blir funnet en koffert» (2).

Den nøkterne beskrivelsen i Gjørv-rapporten av hva som skjedde og hva som ikke skjedde 22. juli 2011 og de tragiske konsekvensene det fikk, kan med god grunn sette følelsene i sving. Rapporten er anbefalt lesning - i sin helhet. Men min egen uvelhet kom for alvor da de ansvarlige - på alle nivåer - begynte å kommentere rapporten og si hva de ville gjøre. Det var ikke bare hva som ble sagt, men formuleringene som ble brukt. De virket både skremmende og skremmende velkjente på samme tid.

Allerede samme kveld som rapporten ble lagt frem, fikk man en fornemmelse av dette i programmet Aktuelt på NRK (3). Programleder Ole Torp forsøkte gang på gang å få svar fra justisminister Grete Faremo på hva hun mente med å «ta ansvar». Hun ville ikke svare direkte, men sa: «Jeg er opptatt av at mitt ansvar er å bedre beredskapen i Norge. Jeg ønsker et tett samarbeid med Stortinget. Jeg ønsker en grundig gjennomgang av politiet. Det er en ledelsesutfordring. Det er en operativ utfordring. Og vi må ha godt grunnlag også for å introdusere strategisk bruk av IKT og kommunikasjonssystemer på en langt bedre måte enn i dag.» Svaret fikk Ole Torp til å gjøre et siste forsøk: «Hva er det som skal til av feil begått på høyt nivå i politiet for at man skal kunne si at dette er en grov tjenesteforsømmelse? Er det ikke en grov tjenesteforsømmelse å komme så sent til Utøya at
20 menneskeliv kunne vært spart?» Til det svarte Faremo: «I dag vil jeg ikke svare på den type spørsmål i respekt for det grundige arbeidet som ligger i rapporten.» Hva har man å stille opp mot slike svar? I dagene som fulgte er denne typen utsagn kommet på løpende bånd, senest da statsministeren og justisministeren redegjorde for Stortinget 28. august 2012 (4). Denne måten å uttrykke seg på likner til forveksling den nytale vi etter hvert er blitt vant til i helsetjenesten, slik jeg bl.a. beskrev i en leder for to år siden (5).

Det er blitt gjentatt så ofte at man nesten tror det er sant at grunnen til at så mye gikk galt 22. juli 2011 var at noe helt utenkelig hadde skjedd, noe man umulig kunne ha forestilt seg. Men slik var det jo ikke. Tvert imot. Kapittel 4 i Gjørv-rapporten gjennomgår det trusselbildet som var kjent for norske myndigheter før 22. juli og beskriver hvilken kunnskap vi hadde om lærdommen man $\mathrm{i}$ andre land hadde trukket av ulike terrorangrep. Rapporten viser at det var nettopp den form for terrorhandlinger vi opplevde som var å forvente: «22/7 kombinerte Breivik to klassiske terrormål: ett myndighetsmål og ett tett befolket område. Dette er klassiske terrormål, også for ensomme ulver» (kap. 4.3, s. 54). Også metodene er blant de mest vanlige: Store gjødselbomber i kassebiler for å ødelegge bygninger, skyting mot «myke mål» der mange er samlet, f.eks. på skoler, kinoer, T-baner og tog - eller på en ungdomsleir. 77 liv gikk tapt 22. juli 2011, og flere hundre fikk alvorlige skader. Nå vet vi at årsaken til at skadene ble så omfattende, ikke var den uventede situasjonen, men konsekvensen av at faglige innspill ikke ble tatt på alvor, dessuten manglende evne - politisk og administrativt - til å iverksette de rette tiltak de gangene meldingene ble tatt på alvor.

Hvert år skades og dør flere tusen pasienter som følge av uønskede hendelser og medisinsk feilbehandling. Vi har ikke nøyaktige tall. Det i seg selv er ille. Ekstra ille er det at mange av tilfellene kunne vært unngått. Mange av dem er varslede katastrofer. Slik vi nå kan se at 22. juli også var. Vi kunne ikke hindret gjerningsmannen $\mathrm{i}$ å tenke som han gjorde, planlegge som han gjorde, antakelig heller ikke at han iverksatte sin plan. Men skadevirkningene kunne vært begrenset, antall døde og sårede lavere, hvis de ansvarlige hadde lyttet og gjort noe med den informasjonen de hadde.

Jeg har mange ganger tenkt: Hva er det som skal til? Hvor galt skal det gå i helsetjenesten før de som sitter med lederansvaret politisk og administrativt tar situasjonen på alvor og gjør noe? Hvor mange pasienter, pårørende og fagfolk må gi uttrykk for sin bekymring for at systemet ikke er godt nok? At det kan glippe? At det ikke lenger er faglig forsvarlig? Hvor mange gjenglemte gule lapper, rekvisisjoner og prøvesvar skal til? Min foreløpige konklusjon er at selv en hendelse så dramatisk som terrorangrepet 22. juli 2011 neppe ville ført til endringer. For med hånden på hjertet: Hva ville vi fått hvis noe slikt hadde skjedd i helsevesenet? En Sønderland-rapport eller en Gjørv-rapport?

Litteraturlisten finnes på www.tidsskriftet.no 